\title{
The Application of a Cooperative Model in Learning Literary Appreciation Based on Cultural Values and Character Education in Private University
}

\author{
Wijaya Heru Santosa ${ }^{1}$, Rusdian Noor Hermawan ${ }^{2}$, Siti Rochmiati ${ }^{3}$, Anselmus Sudirman ${ }^{4}$ \\ \{wijayaheru@ustjogja.ac.id ${ }^{1}$, rusdian364@gmail.com², rochmiyati_atiek@ustjogja.ac.id ${ }^{3}$, \\ anselmus.sudirman@ustjogja.ac.id $\left.{ }^{4}\right\}$ \\ Universitas Sarjanawiyata Tamansiswa, Indonesia
}

\begin{abstract}
The objectives of this study are to describe (1) the application of cooperative learning and the literary appreciation of based on cultural values and character education in private universities, and (2) Constraints in learning the literary appreciation based on cultural values and character education along with cooperative learning in private universities. Data were collected by using observation, documentation, interview techniques with lecturers and students in 4 private universities, namely Veteran University of Bantara Nusantara,Sukoharjo, WidyadharmaKlaten University, Klaten, Central Java and Sarjanawiyata Tamansiswa University, Yogyakarta, and PGRI University, Yogyakarta. Data were analyzed by using a qualitative model interactive analysis (Miles \&Hubermen, 1992:15-170). The results of the study show that (1) the implementation of cooperative learning in the literary appreciation based on cultural values and character education in private universities is carried out in relation to a variety of lecture methods, group discussions, assignments, and lecture method seminars. The contents of the lecture on literary appreciation are relevant to the characteristics of each private university; (2) constraints in the learning of literary appreciation based on cultural values and character education in line with cooperative learning in private universities include (1) students tend not to have an attitude of pluralism, some students do not understand the meaning of character education and cultural values, lack of interest and reading power of literary appreciation; (2) some lecturers have taught literary appreciation using cooperative models, but they have not had time to study the theory of cooperative learning models; (3) the variety of literary appreciation teaching materials may vary among the privates universities; (4) there is neither teaching material nor cooperative models for literary appreciation based on cultural values and character education.
\end{abstract}

\section{Introduction}

Nowadays, many scholars commit criminal acts such as corruption and terrorism. Many students either do brawls or engage in selling or taking illegal drugs. This indicates that they do not have a strong character [1]. In general, teachers do not understand the nature of character education [2]. Therefore, character education in universities is strongly necessary. Universities are required to develop character education, preserve learning models and cultures by providing consultation services on the implementation of character education in learning and civilizing campus culture (Farida, 2012). The teaching and learning processes 
should stimulate students to actively play a role in discussing lecture materials with active students, and the users of learning methods [3]. This IQF curriculum aims not only to measure sciences and knowledge assessments, but also to foster the character building through learning processes [4].

The subject of this study needs teaching materials that add relevant current knowledge to the competency standards as stated in the IQF, especially in terms of the curriculum of Indonesian Language Education and Literature study program (PBSI). PBSI courses are relevant to the 2013 curriculum in Indonesian subjects particularly in junior and senior high schools oriented to character education that maintains rules of life to achieve a sense of peace in the inner life, both about students' life and their communities [5].

Moreover, learning models are relevant to the formation of individual characters in dealing with other individuals through cooperative models (Andayani, 2012: 234). Using this cooperative learning model, individuals attempt to apply what is called ngreti, ngrasa, and nglakoni (understanding, feeling and implementing) as stated in the teaching materials [6].

In line with observations, the learning of Literature Appreciation courses consisting of prose, poetry and drama studies generally tend to be taught conventionally, and lecturers give assignments to students. In addition, literature appreciation courses have not been integrated with cultural-based character education. Therefore, the objective of this study is to find cooperative learning models in literature appreciation courses that promote character and cultural education in private universities in Special Region of Yogyakarta and Central Java.

In terms of findings, this research will expectedly contribute to the national development of character education for young people, especially students by strengthening local and national cultural values.

\section{CONCEPTS OF COOPERATIVE LEARNING MODEL BASED ON THE CULTURAL VALUES AND CHARACTER EDUCATION}

[7] define the learning model as a conceptual framework used as a guide in learning. [8] define an instructional model is a step-by-step procedure that leads to specific learning outcomes. Thus, the learning model is a conceptual framework that describes a systematic procedure in organizing learning experiences to achieve certain learning goals [9].

According to Slavin (2005: 15), cooperative learning is a teaching and learning activity carried out by encouraging students to work through small groups of 5 people who are heterogeneous. The elements of a cooperative approach (Slavin, 2005: 16) state that students (1) driftin the same perception; (2) have individual and group responsibilities in learningand teaching materials; (3) have the same goal; (4) share assignments between groups; (5) give individual and group evaluations; (6) share leadership and acquired cooperative skills; (7) individual responsibility for the tasks handled by the group. Similarly, Roger and David (2005: 58) state that the five elements of a cooperative approach are (1) the existence of positive interdependence; (2) individual responsibility; (3) promoted interaction; (4) communication between members; (5) group processing.

The aim of cooperative learning is to create pro-academic norms that have an important influence on achieving students' competencies[10]. It means that cultural norms contain nobility and subtlety in all attitudes and forms, as well as contents and behaviors of a whole human life [6].

To achieve these values, Javanese people need to have ethics through character education. The higher the value of a literary work, the more important is the teaching of education [11]. 
[12] states that the function of text allows changes in cultural attitudes. Multicultural novels can play a role in giving enlightenment to schools and colleges [13]. Therefore, students' character education is inseparable from its environment [14]. Of course, students in the Special Region of Yogyakarta and Central Java are inseparable from multicultural values in the Javanese environment. The learning of a literature appreciation is in accordance with the cultural environment that makes children more and more recognized. Such learning models are called a personal cooperative model. This model aims to make children develop their potential personally and synergize with others [9].

The lecturer can choose a literary book that suits the interests of students. The basic elements of a personal cooperative model are (a) syntax that includes (1) students in groups according to the theme of their interest, (2) students take readings on themes according to their groups, then work on exercises in groups, (3) after completing the questions, they will check the results using an answer key in the answer key box. The results of each group contain the assessment rubric. (4) The completed group can take other readings with different themes, and so forth. (5) Learning continues with steps and types of a cooperative learning model. (b) Social system in which the selection of reading sheets is discussed together in one group. Members in groups help each other in terms of readings. (c) The teacher plays a role as a facilitator who organizes a group division, builds a cooperative social environment, negotiation skills, and provides solutions in groups. (d) Supporting system of the classroom environment closely connects to the personal and social needs of each group [9].

\section{Research method}

This research used a combination of procedures [15] and (Sukmadinata, 2005: 182-189) that has an exploration or introduction stage consisting of (1) research and information collection, (2) planning, (3) developing preliminary forms of products. However, this exploratory research is part of a development and descriptive research by collecting data in the field, namely compiling a cooperative model of literary appreciation learning based on cultural values and character education involving students of Indonesian Language Education and Literature in the Special Region of Yogyakarta (at University of PGRI Yogyakarta and Sarjanawiyata Tamansiswa University) and Central Java (Veteran University of Bangun Nusantara, Sukoharjo and Widyadharma University, Klaten). The data collectionincludes descriptions of (1) cooperative learning models of literature appreciation based on character education and cultural values carried out by lecturers in such private universities; (2) obstacles in carrying out the character education and cultural values in the literary learning through cooperative models.

Data were collected using observation, interviews, and documents. In addition, data collection also used a focus group discussion (FGD). Data analysis methods used qualitative models of an interactive analysis (Miles \& Hubermen, 1992-15-170). The data analysis in the first year involves (1) a cooperative model of literature appreciation of learning based on the character and cultural values the lecturers used; (2) the character education and cultural values in the literature appreciation using cooperative models, (3) needs and obstacles in implementing cooperative models of literature appreciation based on cultural values and character education, and (4) needs and obstacles in implementing the character education and cultural values in learning the literature appreciation. 


\section{Results and discussion}

\section{Application of Cooperative Models in Literature Appreciation in Private Universities}

Prose appreciation courses at four private universities are called Study of Indonesian Custom Stories (Univet), Prose Fiction (Unwida), Appreciation and Fiction Studies (UST), and Appreciation and Prose Works (UPY). The subjects in the four private universities in principle have the main topics used as basic competencies in understanding the study, core elements, level and purpose of study, study function, provision and study steps, approach based on the purpose, process-based approach, approach based on the theory, type of prose fiction, intrinsic and extrinsic elements of a prose fiction.

In addition, this course presents the mutual influence between prose, fiction, and society. The review of fiction prose is based on parapratic, emotive, analytical, historical, sociopsychological, didactic goals. The same review also deals with emotive, expressive, cognitive, semantic, structural process approaches. The study is based on the semiotic foundation approach, literary sociology, literary psychology, and post-colonialism.

In teaching and understanding the type, level, purpose and function of the study, first the lecturer designs a college course contract, submits the syllabus of the course, and indicators of achievement. In delivering teaching materials, lecturers use the guideline of lectures and questions and answers. Then the lecturer gives the task to students to discuss the appreciation function. After the discussion, several students were asked to summarize the material, the lecturer held an evaluation by asking the students to discuss the materials, and then the lecturer held a reflection for the teaching activities later. Students were also given individual assignments to look for other learning resources.

In order for students to understand the building blocks in the fiction prose, the lecturer teaches about the types and building blocks of fiction prose and how to find them. The types of fiction prose discussed are novels, and short stories. The elements of fiction prose include themes, story facts, and storytelling. The extrinsic elements are ideology, politics, economics, sociology, psychology, history, and culture. In teaching this course, the lecturer asked the students related to the previous meeting's assignment. Lecturers held a questions and answers session concerning types and elements of prose fiction. After understanding the material, students were asked to conduct group discussions to identify and find out the types and intrinsic elements in the fiction prose. Then, the lecturer discussed the results of students' discussions with his or her colleagues who taught the allied courses.

Lecturers who are teaching the prose fiction and society highlight the influence of society or reader on the prose fiction, the influence of prose fiction on the reading and learning community. For example, students were given the task of a question and answer group on the influence of prose fiction on the community along with identifying the influence of Umar Kayam's novel on Javanese society, and the influence of community culture in Umar Kayam's novel. Then, the lecturer told one of the students to summarize the contents of the material discussed for reporting.

Some students in the four private universities view that culture is an understanding of life habits carried out by the supporting community. People who lead a life without habits are called uncultured people. Teaching literature has an understanding of teaching culture in line 
with books written by the author. In order to understand literary works, they must learn the culture of people when the work was written. To study novels in the 1950s, readers must also read the history of the community at that time. In terms of cultural knowledge and character education, students tend to understand character education as an education that has a sense of responsibility to individuals, society, nation and country. This relates to the general courses provided by institutions, namely National Education Finance. Students also distinguish the value of competition during the time of seizing independence with the value of struggle at the moment. The value of the present-day struggle prioritizes preserving independence and professionalism concerning the specifications of each individual to serve the community realistically.

\section{Constraints in the Application of Cooperative Models in Learning the Appreciation of Cultural Values Based on Literature and Character Education in Private Universities}

\section{Obstacles from Students}

The results of observations and interviews with students in the four private universities show some obstacles in learning the appreciation of literature. One of the obstacles is a method problem used by some lecturers in the literary learning. They tend to use the lecture method through an unsystematic assignment so as to reduce students' motivation to attend lectures. The obstacles also relate to books of literary appreciation and cultural values and character education in the library. Most students want groups of the same familiar or regional backgrounds. Students find it difficult to discuss with others because several groups discuss topics out of the context. In general, constraints result from (1) the lack of understanding of students so that when they are asked to submit the results of the discussion, the results are far from what is expected. (2) In one discussion group, there are only a few students who work while others can only be named after them. d) Limitations of students in seeking information from other friends because they are equally less informed. (3) Students only use references delivered by lecturers. (4) Some students are still shy and afraid to express their ideas in a forum, so that the lecturers find it difficult to deliver lectures. (5) Lack of respect among students who are trying to express ideas. (6) Students are passive in determining discussion groups, (7) lack of interest in reading poems, novels, etc., so that it is difficult for students to learn contextually.

\section{Obstacles from Lecturers}

The results of interviews and observations indicate that lecturers find several obstacles when implementing the literature appreciation course. Lecturers think that the institution does not facilitate the support for the literature appreciation learning, so that it influences the absorption of students toward the literary learning.

The lack of supporting facilities results in the difficulty of lecturers to apply appropriate methods, media and learning techniques to improve students' learning achievement. In addition, lecturers realize that they have actually applied cooperative learning models. Lecturers also see that there is no book model for learning the literature appreciation based on cultural values and character education. 


\section{Conclusions and recommendations}

\section{Conclusion}

The application of cooperative models in learning the literature appreciation is based on cultural values and character education carried out by lecturers, question and answer sessions, group assignments, discussion, and seminars. The contents of the lecture on literature appreciation are relevant to the characteristics of each private university.

Constraints in the application of cooperative models in the learning of cultural valuebased literature appreciation and character education include (1) students tend not to have a pluralism attitude, some students do not understand the meaning of character education and cultural values, students are lack of interest and reading power; (2) some lecturers have taught literature appreciation cooperatively, but have not had time to study the theory of cooperative learning models; (3) a variety of literature appreciation teaching materials can be found in the private universities; (4) there is no teaching material for the literature appreciation that uses cooperative models as a basis for cultural values and character education.

\section{Suggestions}

This section confirms the importance of suggestions such as learning materials for literature appreciation pertaining to cultural values and character education needs to be redesigned. Lecturers need to socialize the cooperative learning models toward literature appreciation in the samples of private universities.

\section{References}

[1] Adams, Francis Hull. 2013. "Using Jigsaw Techinque as an Effective way of Promoting Cooperative Learning among Primary Six Pupils in Fijai.” Interantional Journal Educastion and practice. 2013, 1 (6): 64-67.

[2] Ahmadi, Meysam. 2014. Cultural Hegemony in Charles Dickens's A Tale of Two Cities.” International Journal of Literature and Arts. 2014, 2(4), p 98-103.

[3] Al-Salki, Mahmoud Jamal. 2015. "The Effectiveness of Jigsaw Stategy on the Achievement and Learning Motivation of the 7th Primary Grade Students in the Islamic Education". International Journal of Humanitries and Social Science. Vol. 5 No. 4 ; April 2015.

[4] Andayani. 2012. Aksioma Pembelajaran BahasaIndonesia . Yogyakarta: Yogya Publisher.

[5] Aridanttyo. 2012. "Pentingnya Pendidikan Karakter. https://aridianadityo. Wordpress .com /2012/12/15/pentingnya-pendidikan-berkarakter-bagi-mahasiswa/

[6] Balitbang 2010. Pengembangan Pendidikan Budaya dan Karakter Bangsa. Cetakan Ke-1. Kemendiknas.

[7] Celik, Servet, Kubra Aytin and EsraBayram. "Implementing Cooperative learning in The Language Class room; Opinions of Turkish Teachers of English". Procedia -Social and Behavioral Sciences 70(2013) 1852-1859.

[8] Farida, Ida. 2012. "Model Pendidikan Karakter di PerguruanTinggi, Langkah Strategis dalam Implementasinya di Universitas". Jurnal Administrasi Publik dan Pembangunan. Vol.3. No. 1. Januari-Juni 2012.

[9] Indede, Florence N. 2009. "The pragmatik Kiswahili Political Discoursey The pragmatik Kiswahili Political Discoursey" The Journal of Pan African Studies , vol.2, no.8, 
March 2009 vol.2,, (2001) @akperluyahoo.com indede2001@yahoo.com MasenoUniversity, Kisumu, Kenya Maseno University, Kisum Kenya. p. 2-20.

[10] Jadhap, Arjun danPrashant Mothe. 2010.'Pragmatic Analysis of Abuses in Coolie". The Criterion: An International Journal in English. Vol. 1 Issue III Desember 2010. p. 15.

[11] Joyce, B., Weil, M. \& Calhoun, E. (2004). Models of teaching. New York: Pearson.

[12] Kayam, Umar. 2001. Kelir Tanpa Batas. Cetakan Ke-1. Yogyakarta: Gama Media.

[13] Lickona, Thomas. 2013. Pendidikan Karakter, Panduan Lengkap Mendidik Siswa Menjadi Pintar dan Baik. Cetakan Ke-1. Bandung: Penerbit Nusa Media.

[14] Majelis Luhur Persatuan Tamansiswa. 2013. Ki HadjarDewantara, Pemikiran, Konsepsi, Keteladanan, SikapMerdeka I (Pendidikan). Cetakan Ke-5. Yogyakarta: UST Press.

[15] Majelis Luhur PT. 2013. Ki HadjarDewantara, Pemikiran, Konsepsi, Keteladanan, Sikap Merdeka II (Kebudayaan). Cetakan Ke-5. Yogyakarta: UST Press.

[16] Marhamah and Mulyadi. 2013. "Jigsaw Cooperative learning: A Viable Teaching Learning Stratevgy?.” Jurnal of Educationawl and Social Research MCSR Publishing , Rome-Italy Vo. 3 No. 7 Oktober 2013.

[17] Mawadah, Ade Husnul. 2009.” Semangat Nasionalisme Tokoh Teyi dalam Novel Gadis Tangsi Karya Suparto Brata di Antara Masyarakat Multikultur." Makalah dipresentasikan pada Konferensi Internasional HISKI di Gedung Universitas Pendidikan Indonesia 5-7 Agustus 2009.

[18] Murtisari, ElisabetTitik. 2013. "Some Traditional Javanese Values in NSM: From God to Social Interaction.” International Journal of Indonesian Studies. vol. 12013 p. 110125.

[19] Naviah Yunin Nurun dan Wardan Suyanto. 2014.” Penerapan Model Problem Based Learning untuk Meningkatkan Keterampilan Berpikir Kritis dan Hasil Belajar Siswa". JurnalPendidikanVokasi. Vol. 4 Nomor 12014

[20] Rochmiyati, Siti. 2015."Model Personal Kooperatif dalam Membaca Pemahaman". Prosing Seminar Nasional Pertemuan Ilmiah Bahasa dan Sastra Indonesia (PIBSI) XXXVII, Yogyakarta 2-3 Oktober 2015.

[21] Santosa, WijayaHeru, Cs. 2013. "The Representation of Javanese World in Novels Para Priyayi, Canting, and Gadis Tangsi (Study of Culture and Ideology". Research on Humanities and Social Sciences" vol. 3 no. 22 2013. p 153-159.

[22] Saryono, Djoko. 2008. Etika Jawa dalam Fiksi Indonesia Representasi Nilai-Nilai Etis. Cetakan Ke-1. Malang: PustakaKayutangan.

[23] Saryono, Djoko. 2010. Menafsir Puitika Indonesia Menemu Tilas Budaya Jawa.Cetakan Ke-1. Malang: A3 (Asih Asah Asuh).

[24] Scientific New Magazine Jimbaran. Januari 2017 ISSN 2528-3049

[25] Silaen, Parulian. 2006. "The 'Culture system' in Dutch Indonesia 1830-1870: How Rawls's Original Position Ethics Were Violated.” Research Online The Busines Review. Cambridge, 6(1), December 2006. p. 1-7.

[26] Suroso. .2014. "Multiculturalism in Indonesian Novels As of Culture -Uniting Device." Meditteranean. Journal of Social Sciences. vol. 3 no. 22 September 2014. p 130135.

[27] Suryaman, Maman. 2012. Metodologi Pembelajaran Bahasa. Yogyakarta: UNY Press.

[28] Suwardi. 2011. "Budi Luhur dan Budi Pekerti dalam Perspektif Penghayat Kepercayaan Kejawen Masa Kini.” Disertasi. Pasca Sarjana Universitas 
[29] Suyitno. 2011. "Feminisme dan Nilai Pendidikan Empat Novel Pengarang Perempuan Periode 2000-an (Pendekatan Sosiologi Sastra). Disertasi. Program Pasca Sarjana. Universitas Sebelas Maret Surakarta.

[30] Tim Kurikulum dan Pembelajaran. 2014. Buku Kurikulum Pendidikan Tinggi. Jakarta: Direktorat Pembelajaran dan Kemahasiswaan Ditjen Dikti Kemendikbud.

[31] Triana, Hetti Waluati. "Nilai-Nilai Budaya Minangkabau dalam Karya HAMKA: Analisis Sosio Pragmatik Terhadap Roman di Bawah Lindungan Kabah" Pusat Kajian Budaya. Sabtu 11 Februari 2012. hlm. 1-7.

[32] Wardani, NugraheniEko. 2009. Makna Totalitas dalam Karya Sastra. Cetakan Ke-1. Surakarta: UNS Press.

[33] West, Mary. 2009. "Paradise Lost": 'n Ondersoekna swart arbeid en witongemak in stedelikeSuid-Afrika: Marlene van Niekerk se kortverhaal "Klein vingeroefeningrondom die nosie van hibriditeit". Journals Humanities journals . Journal of Literary Studies articles . September 1, p. 19-21.

[34] Winarni, Retno. 2009. KajianSastra. Cetakan Ke-1. Salatiga: Widyasari Press.

[35] Wright, Laurence. 2010," Resepsi Awal Bukit Fools". Bahasa Inggris di Afrika 31,2(2004):105+ Seni Gale. Humaniora dan Pendidikan Standar Paket. Web. 22 Mei 2010,.hlm. 1-13.

[36] Zaman Citra. Cetakan Ke-1. Jakarta: Dewan Kesenian Jakarta.

[37] Zulnuraini. 2012. "Pendidikan Karakter, Konsep, dan Implementasinya di Sekolah Dasar Kota Palu”. Jurnal Dikdas. No. 1. Vol. 1 September 2012. 